\title{
BIMBINGAN KELOMPOK DENGAN TEKNIK PENGUATAN POSITIF UNTUK MENINGKATKAN KEPERCAYAAN DIRI SISWA SMA DI KOTA BENGKULU
}

\author{
Bayu Saputra, Pudji Hartuti, Arsyadani Mishbahuddin \\ Prodi Bimbingan dan Konseling Fakultas Keguruan dan Ilmu Pendidikan \\ Universitas Bengkulu \\ Bayusaputra1618@gmail.com,pudjihartuti@unib.ac.id, arsyadani@unib.ac.id
}

\begin{abstract}
ABSTRAK
Penelitian ini bertujuan untuk mendeskripsikan pengaruh bimbingan kelompok dengan teknik penguatan positif untuk meningkatkan kepercayaan diri siswa kelas X MIPA B di SMA Negeri 6 Kota Bengkulu.Metode yang digunakan dalam penelitian ini adalah metode eksperimen dengan one group pre-test post-test desain.Sampel penelitian ini sebanyak 10 orang siswa dari kelas X MIPA B di SMA Negeri 6 Kota Bengkulu, yang diambil dengan teknik purposive sampling. Teknik pengumpulan data dalam penelitian ini menggunakan skala kepercayaan diri siswa.Hasil yang diperoleh dalam penelitian ini menunjukkan ada pengaruh yang signifikan layanan bimbingan kelompok dengan teknik penguatan positif terhadap peningkatan kepercayaan diri siswa. Hal ini ditunjukkan dari hasil uji perbedaan sebelum dan sesudah diberikan layanan bimbingan kelompok terhadap tingkat kepercayaan diri siswa yaitu dengan menggunakan uji $z$ yang hasilnya $z=-2.805$ jadi $p>0,05$. Dapat ditarik kesimpulan bahwa pelaksanaan bimbingan kelompok dengan teknik penguatan positif berpengaruh terhadap peningkatan kepercayaan diri siswa di SMA Negeri 6 Kota Bengkulu.
\end{abstract}

Kata kunci: kepercayaan diri, bimbingan kelompok, teknik penguatan positif

\section{THE INFLUENCE OF GROUP GUIDANCE SERVICE WITH POSITIVE REINFORCEMENT TECHNIQUE TO INCREASE SELF CONFIDENCE OF SENIOR HIGH SCHOOL STUDENTS IN BENGKULU CITY}

\begin{abstract}
ABSTRACK
This research aimed to describe the influence of group guidance with positive reinforcement technique to increase the students' self confidence of class X MIPA B in SMAN 6 Kota Bengkulu. The method used in this research was experiment method by means of one group pre-test post-test design. The samples were 10 students of class X MIPA B in SMAN 6 Kota Bengkulu, taken by applying purposive sampling technique. The data collection technique was by using the scale of students' self confidence. The result of this research showed that there was a significant influence of group guidance technique with positive reinforcement technique to the increasing of students' self confidence. It was shown by the result of test differences before and after giving the group guidance technique to the level of students' self confidence that was by using $z$ test which resulted $z=-2.805$ so that $p>0.05$. It can be concluded that the implementation of group guidance with positive reinforcement technique influenced the increasing of students' self confidence in SMAN 6 Kota Bengkulu.
\end{abstract}

Keywords: self confidence, group guidance, positive reinforcement technique 


\section{Pendahuluan}

Siswa yang baru masuk SMA, biasanya dihadapkan pada masalah penyesuaian diri.Mereka diharapkan dapat beradaptasi dengan lingkungan barunya. Dalam proses penyesuaian diri, siswa sering dihadapkan pada persoalan penerimaan dan penolakan oleh teman dalam pergaulanya. Namun, yang lebih penting adalah bagaimana mereka mampu mewujudkan harapan untuk memiliki prestasi yang baik sehingga menjadi kenyataan.Setiap siswa memiliki rasa percaya diri yang berbeda-beda.Ada yang rasa percaya dirinya tinggi dan ada pula yang memiliki rasa percaya diri rendah.

Sikap seseorang yang menunjukkan dirinya tidak percaya diri antara lain: setiap berbuat sesuatu yang penting dan penuh tantangan sering dihadapi dengan sikap keragu-raguan, tidak yakin, cemas, tidak punya inisiatif, cenderung menghindar, mudah patah semangat, dan tidak berani tampil di depan orang banyak (Muslihin, 2014: 2). Rasa tidak percaya diri yang ada pada diri siswa dapat membuat mereka takut untuk melakukan dan mencoba sesuatu. Mereka akan selalu merasa tidak mampu dan takut berbuat salah. Ini membuat mereka tidak mengetahui kemampuan atau potensi apa yang mereka miliki dan ketidakpercayaan diri siswa dapat semakin mengubur kemampuan atau potensi yang dimilikinya. Sedangkan menurut Miskell (dalam Muslihin, 2014: 3), percaya diri adalah kepercayaan akan kemampuan sendiri yang memadai dan menyadari kemampuan yang dimiliki serta dapat memanfaatkannya secara tepat. Tanpa adanya kepercayaan diri yang baik, minat siswa dalam belajar pun akan rendah. Hal tersebut karena suatu keyakinan yang lemah pada diri siswa untuk mencapai hasil belajar yang memuaskan.

Sebelum melakukan penelitian, peneliti terlebih dahulu melakukan observasi kepada siswa di SMA Negeri 6 Kota Bengkulu dan diperoleh data. Berdasarkan hasil pengamatan di sekolah tersebut gejala yang diperoleh yaitu: (1) Siswa tidak berani mengajukan pertanyaan atau menyampaikan pendapatnya kepada guru. (2) Siswa tidak bersedia tampil di depan kelas. (3) Mereka berbicara terbata-bata, dan (4) Mereka menghindarkan diri ketika akan ditanya oleh guru. Hal ini diperkuat dengan perilaku diantaranya: tidak mau maju ke depan kelas, tidak berani tampil bila berhadapan dengan orang banyak, dan tidak mau mengajukan pendapatnya di dalam kelompok, siswa mengalami kesulitan dalam berkomunikasi dengan 
orang lain, baik dalam proses belajar di dalam kelas maupun dalam suasana informal di luar kelas.

Layanan Bimbingan Kelompok dipandang tepat untuk membantu siswa membangun sikap sosialnya. Layanan bimbingan kelompok merupakan media dalam upaya membimbing siswa dengan memanfaatkan dinamika kelompok untuk mencapai tujuan bersama. Dengan layanan bimbingan kelompok siswa diharapkan dapat saling berinteraksi antar-anggota kelompok dengan berbagaipengalaman, pengetahuan, dan ide mengenai pentingnya upaya-upaya dalam membangun kepercayaan dirinya.

Menurut Sukardi (2008: 64), layanan bimbingan kelompok yaitu layanan bimbingan yang memungkinkan sejumlah peserta didik secara bersama-sama memperoleh berbagai bahan dari narasumber tertentu yang berguna untuk menunjang kehidupannya sehari-hari, baik sebagai individu, pelajar, anggota keluarga maupun anggota masyarakat untuk pertimbangan dalam pengambilan keputusan. Menurut Romlah (2001: 3) "bimbingan kelompok merupakan salah satu teknik bimbingan yang berusaha membantu individu agar dapat mencapai perkembangannya secara optimal sesuai dengan kemampuan, bakat, minat, serta nilai-nilai yang diikutinya dan dilaksanakan dalam situasi kelompok". Bimbingan kelompok dapat ditujukan untuk mencegah timbulnya masalah pada siswa dan mengembangkan potensi siswa.

Angelis (dalam Yusnita, 2011: 15), menjelaskan bahwa kepercayaan diri adalah suatu keyakinan dalam jiwa manusia bahwa tantangan hidup apapun harus dihadapi dengan berbuat sesuatu.Dengan demikian kepercayaan diri merupakan kesediaan untuk melakukan sesuatu, bukan berorientasi kepada hasil, Karena hasil merupakan bagian akhir yang tidak bisa ditebak oleh manusia. Oleh karena itu, adanya kemauan yang kuat menghadapi hidup dibutuhkan kepercayaan diri yang kuat.Lindenfield (dalam Pinasti, 2011: 26) "bahwa orang yang percaya diri ialah orang yang merasa puas dengan dirinya".

Kepercayaan diri merupakan suatu keyakinan dalam jiwa manusia bahwa tantangan hidup apapun harus dihadapi dengan berbuat sesuatu.Kepercayaan diri lahir dari kesadaran jika seorang individu memutuskan untuk melakukan sesuatu, sesuatu itu pula yang harus dilakukan. Kepercayaan diri itu akan datang dari kesadaran seorang individu bahwa individu tersebut memiliki tekad untuk melakukan 
apapun, sampai tujuan yang diinginkan tercapai. Sedangkan Hambly (dalam Yusnita, 2011: 16), kepercayaan diri lebih banyak berkaitan dengan hubungan seseorang dengan orang lain dan dengan cara tidak merasa inferior di hadapan siapapun dengan merasa sama baiknya dengan orang lain, tidak merasa canggung atau rikuh apabila menghadapi banyak orang serta dapat bergaul dengan siapa saja yang diinginkan.

Menurut Gazda (1999: 309-310) "bimbingan kelompok di sekolah merupakan kegiatan informasi kepada sekelompok siswa untuk membantu mereka menyusun rencana dan keputusan yang tepat".Sedangkan menurut Prayitno (1994: 309) "Bimbingan Kelompok adalah layanan yang diberikan dalam suasana kelompok". Bimbingan ini ditujukan untuk merespon kebutuhan dan minat para peserta didik.Topik yang didiskusikan dalam bimbingan kelompok ini adalah masalah yang bersifat umum (common problem) dan tidak rahasia.

Menurut Corey (dalam Ardita, 2014: 3), dalam bimbingan kelompok dibutuhkan penguatan positif untuk membentuk pola prilaku dengan memberikan penguatan segera setelah tingkah laku yang diharapkan muncul.Teknik ini dipilih karena cukup ampuh untuk mengubah tingkah laku.Penguatan diberikan ketika individu menunjukkan tingkah laku yang diinginkan.Menurut Wahid, dkk (2010: 116), pada umumnya penghargaan mempunyai pengaruh positif dalam kehidupan manusia yakni dapat mendorong seseorang untuk memperbaiki tingkah lakunya dan meningkatkan usahanya. Alasan peneliti menggunakan teknik ini karena teknik ini dirasa tepat dalam menangani permasalahan siswa yaitu kurangnya rasa percaya diri pada siswa kelas X MIPA B SMA Negeri 6 Kota Bengkulu.

\section{Metode Penelitian}

Desain yang digunakan dalam penelitian adalah pre-experimental, yang dilakukan dengan memberikan perlakuan (treatment) tertentu kepada subjek penelitian (one group pretest-posttest design). Dalam penelitian ini subjek dikenakan dua kali pengukuran. Dengan demikian perlakuan dapat diketahui lebih akurat, yaitu membandingkan hasil yang diperoleh sebelum diberikan perlakuan terdapat 1 orang siswa dalam kategori sedang, 8 orang siswa dalam kategori rendah dan 1 orang siswa dalam kategori sangat rendah. Setelah mendapat perlakuan 
meningkat menjadi 1 orang dalam kategori tinggi dan 9 orang siswa meningkat menjadi kategori sedang.

Perbedaan antara pre-test danpost-test diasumsikan sebagai efek dari treatment atau eksperimen. Desain tersebut digambarkan sebagai berikut:

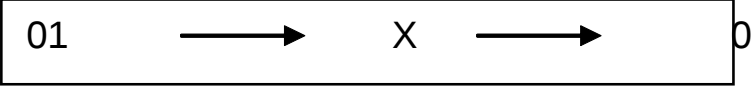

Keterangan :

01 : Pre-test (tes yang dilakukan sebelum bimbingan kelompok)

$\mathrm{X}$ : Treatment (pemberian bimbingan kelompok)

02 : Post-test (tes yang dilakukan sesudah bimbingan kelompok

Populasi dalam penelitian ini adalah siswa yang berjumlah 30 orang dari kelas $\mathrm{X}$ MIPA B di SMA Negeri 6 Kota Bengkulu. Adapun sampel yang digunakan dalam penelitian ini berjumlah 10 orang siswa yang diperoleh dari pemberian angket kepercayaan diri untuk mengukur tingkat kepercayaan dirinya, sebelum angket diberikan peneliti melakukan validitas isi kepada 3 dosen ahli yaitu Prof. Dr. Pudji Hartuti, Psikolog, Dr. Hadiwinarto, M.Psi, dan Dr. Wasidi, M.Pd. Kemudian peneliti juga menggunakan reliabilitas untuk melihat keajekan dari instrumen yang peneliti gunakan. Setelah hasil dari uji validitas dan uji reliabilitas sudah benar dan hasilnya sudah tetap maka peneliti baru memberikan angket kepada siswa yaitu untuk mengukur tingkat kepercayaan diri siwa kelas X MIPA B di SMA Negeri 6 Kota Bengkulu.

\section{Hasil dan Pembahasan}

Analisis hasil pre-test dan pos-test kepercayaan diri siswa kelas X MIPA B SMA Negeri 6 Kota Bengkulu.

Pre-test

\begin{tabular}{lcl}
\hline Interval & Frekuensi & Kategori \\
\hline$>\mathbf{1 7 7}$ & - & Sangat tinggi \\
$\mathbf{1 6 0}-\mathbf{1 7 6}$ & - & Tinggi \\
$\mathbf{1 4 2}-\mathbf{1 5 9}$ & 1 & Sedang \\
$\mathbf{1 0 7 - 1 4 1}$ & 8 & Rendah \\
$\leq \mathbf{1 0 6}$ & 1 & Sangat rendah \\
Total & 10 & - \\
\hline
\end{tabular}

Hasil yang didapat sebelum diberikan layanan bimbingan kelompok dengan teknik penguatan positif adalah terdapat 8 siswa RDW, MSAH, TAA, ANH, DPS, YMY, ZAA, dan VTY dalam kategori rendah, dan 1 orang siswa DPRY dalam kategori sangat rendah, serta 1 orang yang berinisial AAOP dalam katagori sedang. Hal ini diketahui setelah diberikan angket pre-test kepercayaan diri. Sebelum diberikan layanan bimbingan kelompok 
skor kepercayaan diri 1 orang siswa (ANH) dalam kategori sedang dengan skor antara 142 - 159, serta dalam kategori rendah sebanyak 8 orang siswa yaitu, RDW, MSAH, TAA, AAOP, DPS, YMY, VTY dan ZAA. Satu siswa yaitu DPRY berada dalam kategori sangat rendah dengan skor $\leq 106$ yang memiliki mean sebelum diberikan perlakuan yaitu sebesar 118 .

Hasil analisis data deskriptif pre-test dari 10 orang siswa yang mengalami kepercayaan diri sedang, rendah, dan sangat rendah, siswa yang menjadi sampel dalam penelitian ini merupakan gambaran kecil dari masalah kepercayaan diri yang rendah dari jumlah siswa keseluruhan di sekolah. Berdasarkan informasi dari guru pembimbing, ada beberapa orang siswa yang memiliki ciri kepercayaan diri yang rendah yaitu susah bersosialisasi dengan lingkungan sekitarnya, berbicara mereka masih terbata-bata, kurang aktif dalam belajar, dan berpikiran negatif.

\section{Post-test}

\begin{tabular}{lcl}
\hline \multicolumn{1}{c}{ Interval } & Frekuensi & Kategori \\
\hline$>\mathbf{1 7 7}$ & - & Sangat tinggi \\
$\mathbf{1 6 0 - 1 7 6}$ & 1 & Tinggi \\
$\mathbf{1 4 2}-\mathbf{1 5 9}$ & 9 & Sedang \\
$\mathbf{1 0 7 - 1 4 1}$ & - & Rendah \\
$\leq \mathbf{1 0 6}$ & - & Sangat rendah \\
Total & 10 & - \\
\hline
\end{tabular}

Setelah diberikan layanan bimbingan kelompok dengan teknik penguatan positif, terjadi peningkatan kepercayaan diri pada siswa.Hal ini terlihat dari hasil post-test yang telah diberikan. Dari sepuluh orang anggota kelompok satu siswa dengan inisial DPRY yang sebelumnya masih tergolong dalam tingkat kepercayaan diri sangat rendah dan setelah mendapatkan layanan bimbingan kelompok menjadi satu orang siswa dengan kategori tinggi. Sembilan siswa yang awalnya rendah dengan nama inisial RDW, MSAH, TAA, DPS, ANH, YMY, ZAA, AAOP dan VTY meningkat dengan kategori sedang. Perubahan skor tersebut meningkat setelah diberi treatment melalui bimbingan kelompok dengan teknik penguatan positif yang dibahas dengan berbagai "topik tugas" yang berkaitan dengan kepercayaan diri siswa yang merupakan kisi-kisi angket serta diberikan penguatan positif yang dapat meningkatkan kepercayaan diri setelah mendapatkan treatment yang dilakukan peneliti sebanyak lima kali pertemuan. Dengan demikian topik tugas yang diberikan oleh peneliti dalam bimbingan kelompok dapat mendorong pengembangan kepercayaan diri siswa.

Teknik yang digunakan adalah teknik penguatan positif karena pada umumnya 
penghargaan mempunyai pengaruh positif dalam kehidupan manusia yakni dapat mendorong seseorang untuk memperbaiki tingkah lakunya dan meningkatkan usahanya.Untuk meningkatkan kepercayaan diri, siswa diberikan pujian, penghargaan agar siswa semakin termotivasi menjadi lebih percaya diri (Wahid, dkk (2010: 116). Dalam penelitian ini, peneliti memilih menggunakan teknik penguatan positif untuk meningkatkan kepercayaan diri siswa.Penguatan positif adalah pembentukan suatu pola tingkah laku dengan memberikan ganjaran atau penguatan segera setelah tingkah laku yang diharapkan muncul.Teknik penguatan positif ini dianggap efektif karena pada umumnya penghargaan mempunyai pengaruh yang positif karena dapat mendorong seseorang mengubah perilakunya dan meningkatkan usahanya.

Teknik penguatan positif ini diberikan untuk meningkatkan kepercayaan diri siswa.Dalam teknik penguatan positif siswa diberi pujian serta penghargaan dengan tujuan agar mereka semakin termotivasi untuk meningkatkan kepercayaan dirinya. Hal ini dilakukan dengan cara berdiskusi dalam bimbingan kelompok dengan menggunakan topik tugas. Dari diskusi yang dilakukan menunjukkan keaktivan siswa dalam mengemukakan pendapat maupun saran meningkat. Topik yang digunakan dalam bimbingan kelompok ini ada 7 topik, yaitu: cinta diri, pemahaman diri, tujuan yang jelas, berpikir positif, komunikasi, penampilan diri, dan pengendalian diri.

\section{Uji Hipotesis}

\begin{tabular}{lc}
\hline \multicolumn{2}{c}{ Post-test - Pre-test } \\
\hline $\mathbf{Z}$ & $-2.805^{\mathrm{a}}$ \\
Sig.(2-tailed) & $\mathbf{. 0 0 5}$ \\
\hline
\end{tabular}

Hasil uji hipotesis yang telah dilakukan menunjukkan signifikansi $0.000<$ 0.05 yang berdasarkan kriteria penerimaan atau penolakan hipotesis Ho ditolak dan $\mathrm{Ha}$ diterima maka diperoleh hasil bahwa ada perbedaan yang signifikan kepercayaan diri siswa sebelum dan sesudah diberikan layanan bimbingan kelompok dengan teknik penguatan positif pada siswa kelas $X$ MIPA B di SMA Negeri 6 Kota Bengkulu.

Data hasil penelitian dari pre-test dan post-test juga menunjukkan bahwa secara keseluruhan masalah rendahnya kepercayaan diri siswa menjadi lebih tinggi setelah mendapatkan perlakuan (treatment) jika dibandingkan dengan sebelum mendapatkan perlakuan (treatment). Hal ini diungkapkan anggota kelompok dari 
pengalaman bimbingan kelompok dengan teknik penguatan positif, seperti halnya siswa yang kurang percaya diri, dengan adanya bimbingan kelompok yang menggunakan teknik penguatan positif, siswa berubah menjadi memiliki kepercayaan diri lebih baik.

Disimpulkan bahwa pemberian bimbingan kelompok dengan teknik penguatan positif sesuai dengan prosedur yaitu paired-samples t-tes, prosedur yang digunakan untuk membandingkan dua jenis data atau mean yang berasal dari sampel yang sama dan cukup efektif untuk meningkatkan kepercayaan diri siswa. Penggunaan teknik penguatan positif sebagai strategi pemecahan masalah yang dialami oleh siswa. Dalam meningkatkan kepercayaan diri siswa sebaiknya mengetahui pentingnya dan cara yang dapat dilakukan untuk meningkatkan kepercayaan dirinya. Pelaksanaan teknik penguatan positif ini sesuai untuk dilakukan dalam layanan bimbingan kelompok. Penerapan teknik penguatan positif ini mampu meningkatkan kepercayaan diri siswa dengan cara diberikan pujian dan penghargaan.

Berikut ini adalah siswa yang mengalami peningkatan kepercayaan diri yang berinisial DPRY yang awalnya sangat rendah menjadi tinggi, dan 9 siswa dengan inisial ANH, DPS, DPRY, MSAH, RDW, TAA, VTY, YMY, ZAA yang awalnya rendah menjadi sedang.

Selama 5 kali pertemuan yang sudah dilakukan, anggota kelompok semakin akrab dan mulai terbiasa dalam memahami sesama anggota kelompok. Dengan dinamika kelompok siswa menjadi terbuka pada diri sendiri dan terbuka kepada orang lain. Sesuai dengan uraian tersebut dapat disimpulkan bahwa ada perbedaan kepercayaan diri siswa sebelum dan sesudah diberikan layanan bimbingan kelompok dengan teknik penguatan positif pada siswa kelas X MIPA B di SMA Negeri 6 Kota Bengkulu. Hal ini menunjukkan bahwa layanan bimbingan kelompok dengan teknik penguatan positif ternyata efektif untuk meningkatkan kepercayaan diri siswa.

\section{Kesimpulan}

Berdasarkan hasil penelitian yang telah dilakukan, dapat disimpulkan bahwa rendahnya kepercayaan diri yang dimiliki siswa sebelum diberikan layanan bimbingan kelompok dengan teknik penguatan positif dari 30 orang siswa di kelas X MIPA B didapat 10 orang siswa mayoritas berada dalam kategori rendah. Setelah diberikan 
layanan bimbingan kelompok dengan teknik penguatan positif, dari 10 orang siswa yang mengalami rendahnya kepercayaan diri, 1 orang siswa meningkat menjadi tinggi dan 9 orang siswa meningkat menjadi sedang. Dapat disimpulkan bahwa terdapat pengaruh tingkat kepercayaan diri siswa kelas X MIPA B di SMA Negeri 6 Kota Bengkulu setelah diberikan treatment yaitu layanan bimbingan kelompok dengan menggunakan teknik penguatan positif.

\section{Daftar Pustaka}

Ardita, dkk.(2014). Efektivitas Model Konseling Behavioral Teknik Latihan Asertif danTeknik Penguatan Positif dalam Meningkatkan Academic SelfEfficacy Pada Siswa Kelas VII.Jurnal Jurusan Bimbingan Konseling. Universitas Pendidikan Ganesha Singaraja.

Gazda, G M. (1984).Group Counseling Developmental Approach. Boston: Allyn and Bacon, Inc.

Martono, N. (2014). Metode Penelitian Kuantitatif Analisis Isi dan Analisis Data Sekunder. Jakarta: Raja Grafindo Persada.

Prayitno.(1995). Layanan Bimbingan dan Konseling (dasar dan profil).Padang : Ghalia Indonesia.

Prayitno.(1994). Dasar-dasar Bimbingan dan Konseling.Jakarta; rineka cipta.
Sukardi.(2008). Evaluasi Pendidikan Prinsip dan Operasionalnya. Yogyakarta: Bumi Aksara.

Wahid Murni, dkk. (2010). Keterampilan Dasar Mengajar.Yogyakarta: ArRuzz Media.

Yusnita, Y. (2011). Kepercayaan Diri Siswa yang Aktif Mengikuti Layanan Bimbingan Kelompok di SMP Negeri 23 Pekanbaru.Skripsi.Universitas Islam Negeri Sultan yarif Kasim Riau Pekan Baru. 